\title{
Patterns of Variation in the Seed Morphology of Iva annua var. macrocarpa, an Extinct North American Domesticate
}

\author{
Andrew W. Weiland ${ }^{1 *}$ and Kristen J. Gremillion ${ }^{1}$ \\ ${ }^{1}$ Department of Anthropology, The Ohio State University, Columbus, OH, USA \\ *weiland.8@osu.edu
}

\begin{abstract}
Using measurements from archaeological achenes of the extinct North American cultigen marshelder (Iva annua var. macrocarpa [S.F. Blake] R.C. Jackson), we quantitatively explore patterns of variation of fruit length and width across mid-continental North America. Linear regression shows that while achene length and width increase significantly over time (length: $p$-value<0.0001, $\mathrm{b}=-126.04, \mathrm{r}^{2}=0.1037$, width: $p$-value $<0.0001, \mathrm{~b}=-230.85, \mathrm{r}^{2}=0.0964$ ), overall, regions tend to show more variation. A high incidence of phenotypic variation among domesticated marshelder as measured by coefficient of variation may be a result of introgression with wild stands. An ANOVA Tukey post-hoc analysis of archaeological site samples resulted in homogeneous subsets which correspond to region with some overlap, interpreted as a cline. These results and the low numbers of wild-sized achenes in archaeological marshelder samples of eastern Kentucky support human introduction of domesticated marshelder into this region. Marshelder in the archaeological record reflects the longstanding mixed economies of hunting-gathering and agriculture used by indigenous communities of eastern North America.
\end{abstract}

Received May 26, 2017

OPENひACCESS

Accepted December 12, 2017

DOI 10.14237/ebl.9.2.2018.990

Keywords Paleoethnobotany, Seed morphology, Archaeology, Native North America, Domestication

Copyright (c) 2018 by the author(s); licensee Society of Ethnobiology. This is an open-access article distributed under the terms of the Creative Commons Attribution-NonCommercial 4.0 International Public License (https://creativecommons.org/licenses/by-nc/4.0), which permits non-commercial use, distribution, and reproduction in any medium, provided the original author and source are credited.

Supplementary Files available at ojs.ethnobiology.org/index.php/ebl/article/view/990

\section{Introduction}

While Volney Jones and Melvin Gilmore were the first scholars to present strong evidence for the "Eastern Agricultural Complex" (EAC) originally proposed by Linton (1924), Richard A. Yarnell pushed this research forward by accumulating a large paleoethnobotanical database in which he was able to identify patterns across time and space. As part of this effort, he adopted the procedure of regularly measuring seeds and fruits to identify morphological correlates of domestication in plants native to eastern North America. Yarnell used average lengths of achenes (the dry fruit type characteristic of the aster family, Asteraceae) from the handful of sites available at the time to demonstrate the domesticate status of the weedy annual marshelder or sumpweed (Iva annua L.; in its domesticated form known as I. anпua L. var. macrocarpa [S.F. Blake] R.C. Jackson). Marshelder achene size increased over time in eastern North America (Blake 1939; Jackson 1960; Smith et al. 1992;
Yarnell 1972; Yarnell 1981), quickly surpassing maximum wild dimensions $(4.5 \mathrm{~mm})$ in the Late Archaic period (5000 to $3000 \mathrm{BP}$ ) and increasing gradually thereafter.

This study builds on Yarnell's legacy of using seed morphology to detect overall patterns in the domestication process. However, whereas Yarnell was primarily concerned with the effects of natural selection on average seed and fruit size under domestication, we focus instead on variation in these traits. As Yarnell (1981) notes, there are some exceptions to the trend of increasing mean achene size. Rather than being considered problematic, however, these anomalies can be used to better understand the large-scale cultural behavior that drove selection in prehistoric gardens and fields. For example, phenotypic variability in traits such as seed size is expected to decline as the gene pool of the domesticate becomes increasingly isolated from that of the parent population, but ongoing hybridization 


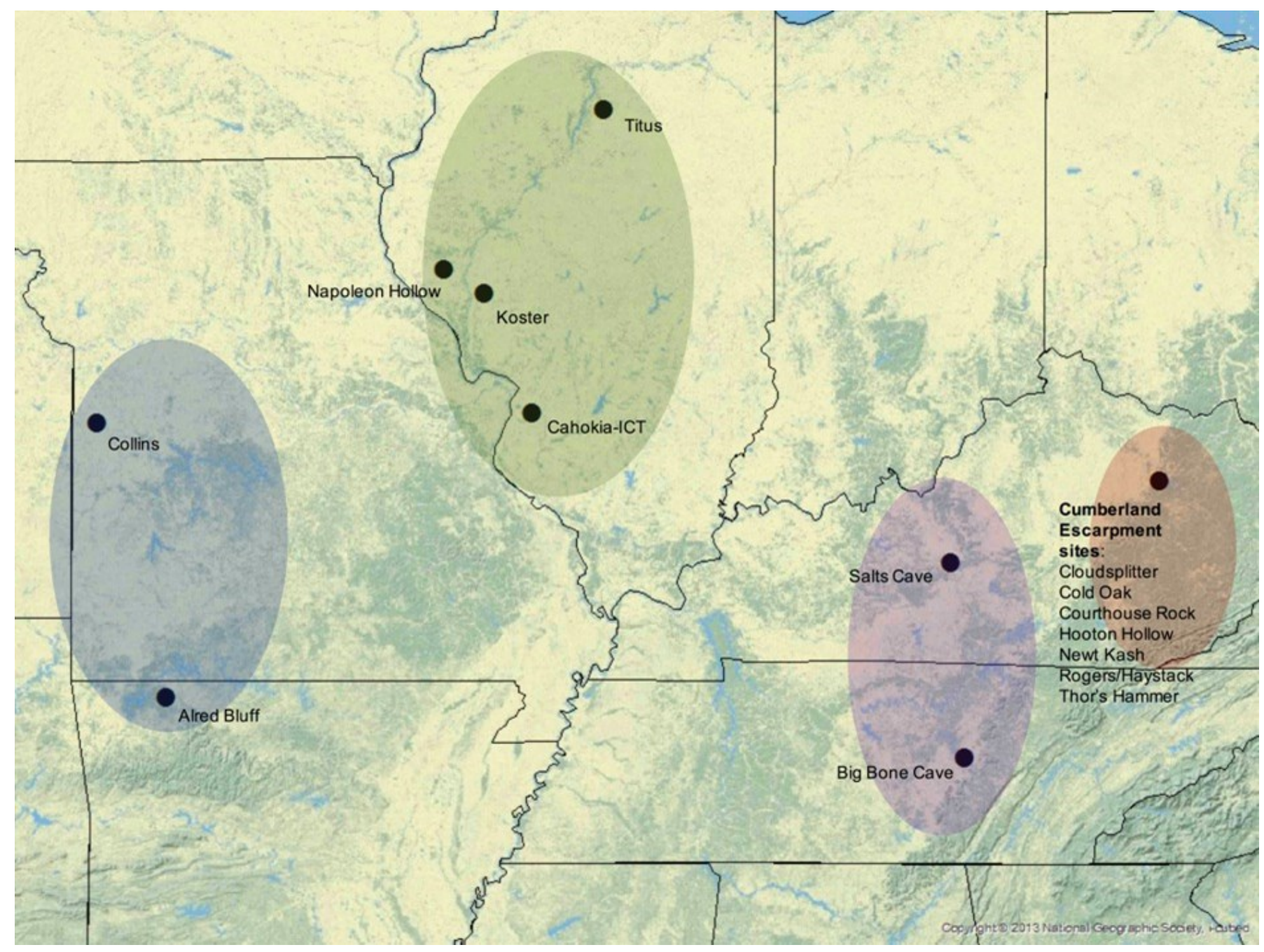

Figure 1 Map of select sites discussed and their accompanying geophysical regions. Blue=Ozark Plateaus, Green=Central Lowlands, Purple=Interior Low Plateau, Orange=Appalachian Plateau sites, mostly located in the Cumberland Escarpment. (Basemap: National Geographic, i-cubed 2013)

may interfere with this process (Allaby 2010). In contrast, imported seedstock might be highly uniform morphologically when first introduced, with subsequent gene flow dependent upon human agency.

To explore this variability, we analyze data from Central Lowland sites in central and southern Illinois, Ozark Plateaus sites in Arkansas and Missouri, Interior Low Plateaus sites in Kentucky and Tennessee, and Appalachian Plateau sites, mostly from the Cumberland Escarpment in Kentucky (Figure 1). In doing so, we can take advantage of the reports, notes, and publications that have accumulated since Yarnell wrote his piece on sunflower and sumpweed achene size in the first volume of the Journal of Ethnobiology in 1981, and more can be said using quantitative methods to analyze these measurements. We use statistics to examine trends in average marshelder achene dimensions over time to further characterize the patterns identified in Yarnell's work (1972, 1981). We also consider the effects that reproductive isolation of a small initial gene pool might have had on the rate of change and range of variation in achene dimensions. These patterns may be useful for differentiating between cases of in situ gradual domestication and introduction of imported seedstock into new locations. 


\section{Seed and Fruit Morphology of Iva annua}

Seed morphology can provide domestication researchers with much-needed information about the rates of change, patterns, and diffusion of domesticates (Fuller et al. 2012; Gremillion 1993; Harlan et al. 1973; Mueller 2017; Smith 1985; Yarnell 1981). Phenotypic change observed in archaeobotanical evidence represents the genetic biophysical imprint resulting from the selective environment created by long-term human adaptive strategies. Tracking this domestication process through morphological changes in the phenotype creates a window through which archaeologists can view the selective pressures created by prehistoric populations' interactions with plants. Researchers have undertaken analyses of this kind for several of the native crop plants known as the EAC. Several of these plants exhibit traits characteristic of the adaptive syndrome of domestication (Fuller 2007; Harlan et al. 1973), such as increased seed and fruit size and reduction of structures that inhibit germination (Gremillion 1993; Mueller 2017; Smith 2006; Yarnell 1972). Seed size is believed to be under relatively strong selection in human-modified habitats because of competition between seedlings that favors rapid germination and large reserves of food for early growth (Harlan et al. 1973), and the differing selective effects of germination in the richer, less risky environments created by anthropogenic landscapes and agroecosystems (Leishmann et al. 2001).

Among the EAC crops that demonstrate this trend is the weedy annual marshelder, which was most likely grown for its protein-rich oily kernels. Over 50 years of study has demonstrated that selection for larger kernels and surrounding achenes took place under human influence between roughly 3620 and 600 years cal BP. The domesticated form of marshelder declined in human use in the Late Prehistoric around $600 \mathrm{cal} \mathrm{BP}$, eventually becoming extinct, probably due to disuse and introgression with wild populations of this wind-pollinated species. Wild marshelder, before its domestication-as today-had an average achene length of around $3 \mathrm{~mm}$, never surpassing $4.5 \mathrm{~mm}$ (for an exception, see Mueller et al. 2017), whereas domesticated marshelder often reached $9 \mathrm{~mm}$, frequently documented with a mean sample length of $6 \mathrm{~mm}$ in archaeological samples (Yarnell 1972, 1981). Smith (1992) has demarcated the minimum measurement to consider marshelder domesticated at a mean of $4.0-4.2 \mathrm{~mm}$ long in an archaeological context.

The earliest evidence of wild marshelder in an archaeological context comes from the Titterington phase of the Koster Site in the Illinois River valley and dates to $6055 \mathrm{cal} \mathrm{BP}$ (Asch and Asch 1978). Mean length and width for these achenes fall well within the wild size range $(2.3 \times 1.9 \mathrm{~mm}, n$ length $=284, n$ width=340) and well below the domesticate cutoff of 4.0-4.2 $\mathrm{mm}$. Other early examples from Illinois include the Cahokia Interpretive Center Tract (ICT) site (3321 BP) (Nassaney et al. 1982), and Titus Horizon 2 (3335 BP) (Asch and Asch 1978). These findings indicate that free-living marshelder was present locally in the Central Lowlands, as it is today, a frequent colonizer of disturbed floodplain soils and anthropogenic habitats (Asch and Asch 1978; Smith 1992).

The earliest evidence for domesticated marshelder is from 44 achenes from Feature 20 at Napoleon Hollow, dated to $3920 \pm 40 \mathrm{cal} \mathrm{BP}$ (Smith and Yarnell 2009). These specimens averaged $4.2 \mathrm{~mm}$ in length. Domesticated marshelder achenes at Napoleon Hollow and Riverton (3370 $\pm 40 \mathrm{cal} \mathrm{BP})$ sites in Illinois predate its first appearance on the Appalachian Plateau of eastern Kentucky, which comes from the Hooton Hollow rock shelter and has been directly dated to 3315 cal BP (Gremillion 1996). The scarcity of marshelder in modern Appalachian Plateau flora (Black 1963, Cowan 1985) and the lack of wild-size marshelder from archaeological collections suggest that human intervention brought marshelder to the Appalachian Plateau, already in domesticated form. Black (1963) and Cowan (1985) claimed that there were no modern wild stands in Kentucky. But, these publications predate electronic sources such as the USDA PLANTS (USDA, NRCS 2017) website and many plant guides using updated surveys. While such sources correctly identify the presence of modern wild marshelder in many counties in states formerly thought to be outside its natural range, a systematic literature and herbarium review has yet to be executed detailing wild marshelder's modern ubiquity and density in various regions. It seems that marshelder stands exist in the Appalachian Plateau, but not as densely or ubiquitously as in locations in the Ozark Plateaus (Natalie Mueller, personal communication). It is also difficult to determine what the existence of modern wild stands of marshelder means in terms of their prehistoric distribution. Some anecdotal evidence that has yet to be tested points to marshelder's 
existence close to archaeological sites, which may represent remnant populations from human plantings. If this interpretation is accurate, the expanded metric database for marshelder should reveal the following patterns:

1. New data will support the inference that selection under human management drove an increase in achene length and a reduction of variance in this characteristic over time.

2. In locations where marshelder was domesticated from wild populations, or where domesticated marshelder was introduced into areas with wild populations, the trend to increased achene size and reduction of variability in this trait will be inhibited by ongoing hybridization.

3. In locations where marshelder was introduced as a domesticate, and wild marshelder was absent, variation in achene size should be relatively low because of reproductive isolation from wild populations. There should be a directional trend to larger achenes and low variability compared to locations where marshelder was domesticated from wild populations.

4. Each regional population should have an achene size distribution, forming a geographical cline with domesticated marshelder in adjacent regions.

\section{Materials and Methods}

To evaluate this model of marshelder domestication, we have assembled a body of metric data from the mid-continental United States. This area has the longest history of systematically-collected plant remains and includes sites both within and outside the densest areas of marshelder's modern natural range (Black 1963; USDA, NRCS 2017). This study incorporates raw data gleaned from site reports and published literature and uses averages and ranges of assemblages when raw measurements were not available. Small samples (i.e., $<20 n$ ) were useful for mean length and width but in some cases, yielded a coefficient of variation (CV) that was probably artificially high. Sample sizes were most useful for all tests used when they neared $100 \mathrm{n}$. In addition to publications (Supplemental Table 1), some measurements were gleaned from notes of the second author and spreadsheets compiled by George Crothers (also available in Supplemental Table 1). Crothers and Faulkner (1991) reported statistical analyses of marshelder at the Society of Ethnobiology Conference and graciously allowed us to make use of their unpublished data compiled for this presentation. In the case of Courthouse Rock, Kentucky, Weiland (2013) used a dissecting microscope with a reticule eyepiece at a magnification of $10 x$, which allowed for accuracy of measurement to $0.1 \mathrm{~mm}$. Desiccated, uncarbonized achenes were measured at the longest part along the center, from the proximal hilum to the distal end of the fruit. Width was measured at the widest section of these relatively flat fruits. Published works did not always describe methods of measurement, but as these are fairly straightforward we believe they are comparable. For carbonized remains from published works that did not already use a correction factor, we used the Asch and Asch (first described in Stafford et al. 1985) method to correct carbonized measurements to approximate fresh achene and kernel measurements. Per this method, achene length and width were divided by 0.90 . For kernels without surrounding achene, the following formulas were followed to replicate uncarbonized seeds with achenes still attached: 1) Uncarbonized achene length $=1.36 \times$ (carbonized kernel length) + $0.17 \mathrm{~mm}$; 2) Uncarbonized achene width $=1.45 \mathrm{x}$ (carbonized kernel width) $-0.06 \mathrm{~mm}$. We analyze temporal trends and patterns of variation using ANOVA with post-hoc analysis, linear regression, and comparing CV. Quantitative analysis and graphic representations were made using $\mathrm{R}$ Studio 1.0.153. Different sets and subsets of our data were used based on the requirements of each analysis or figure. Linear regressions using site mean (Figures $2 \mathrm{~A}$ and $2 \mathrm{~B}$ ) required a radiocarbon date associated with the marshelder sample $(n=17)$. Linear regressions using individual achene measurements (Figures 2C and 2D) required length and width measurements for all achenes and radiocarbon dates associated with the marshelder sample: $n=994$ from 11 sites. The ANOVAs testing period and region required individual achene measurements in samples exceeding 20 achenes and a context directly assigned a period by the excavators: $n=994$ from 11 sites. Determining CV and $95 \%$ confidence intervals required that mean, $n$, and standard deviation (SD) be reported by analysts in samples exceeding 20 achenes: ten archaeological sites and 12 modern stands were used. Figures 3A, 3B, 4A, and $4 \mathrm{~B}$ showing achene length in relation to period and region required a site mean and a context directly assigned a period by the excavators: $n=50$. 

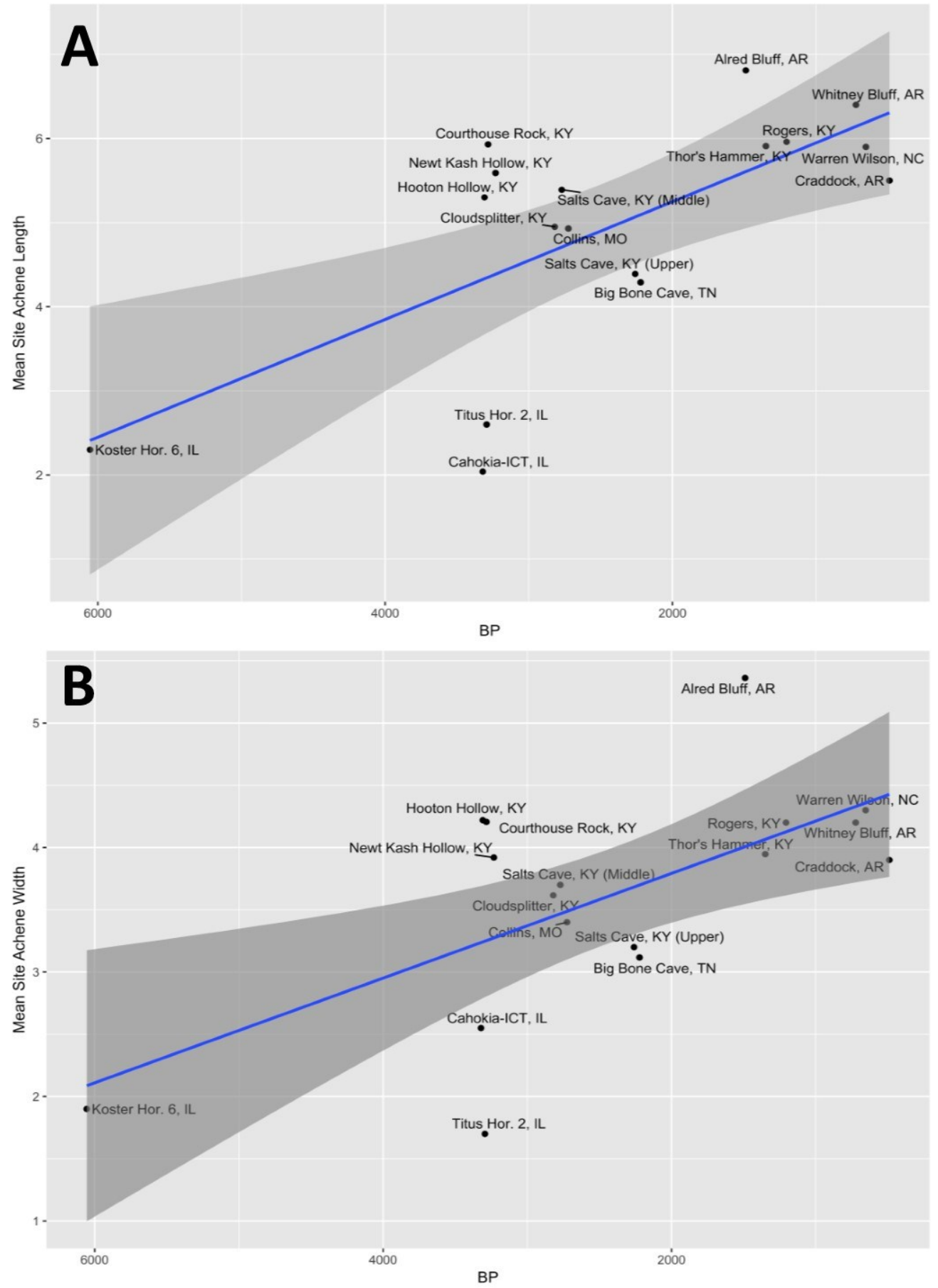

Figure 2 Linear regressions of site mean achene measurements vs. years calibrated $B P(A, B)$, and individual achene measurements vs. years calibrated BP (C, D). Blue lines represent slope (b), and gray areas represent $95 \%$ confidence interval. A) Linear regression for mean site achene length vs. years calibrated $B P(n=17, t=-3.624, p$-value $=0.0025, b=-666.9$, $\left.r^{2}=0.4669\right)$ B) Linear regression for mean site achene width vs. years calibrated BP ( $n=17, t=-3.187, p$-value $<0.00612, b=-$ 959.9, $\left.r^{2}=0.4037\right)$ C) Linear regression for achene width vs. years calibrated $B P(n=994, t=-10.71, p$-value $<0.0001, b=-$ $\left.126.04, r^{2}=0.1037\right) D$ ) Linear regression for achene width vs. years calibrated $B P(n=994, t=-10.26, p$-value $<0.0001, b=-$ $\left.230.85, r^{2}=0.0964\right)$.

(continued on next page) 

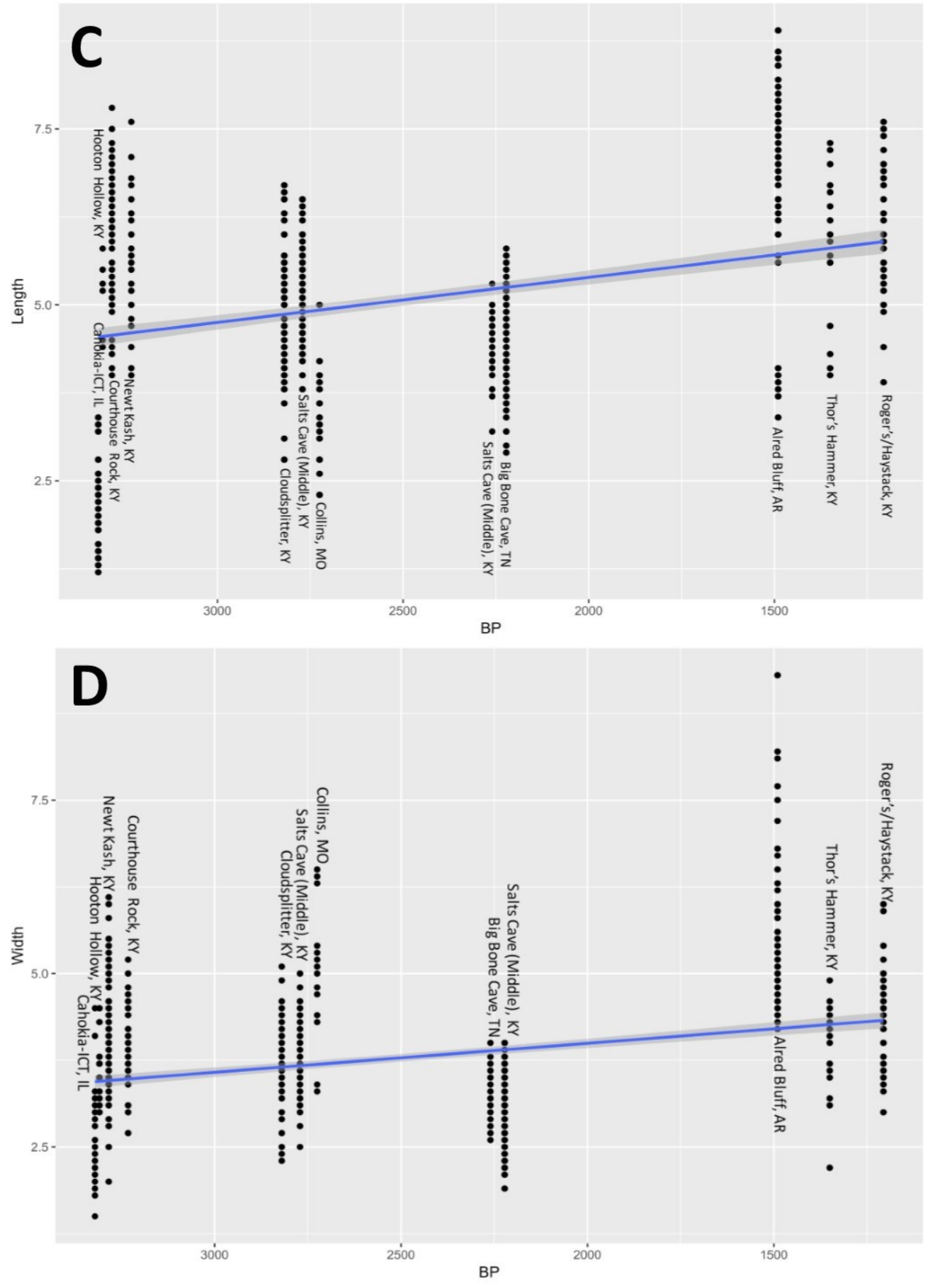

(continued from previous page)

Figure 2 Linear regressions of site mean achene measurements vs. years calibrated $B P(A, B)$, and individual achene measurements vs. years calibrated BP (C, D). Blue lines represent slope (b), and gray areas represent $95 \%$ confidence interval. A) Linear regression for mean site achene length vs. years calibrated $B P(n=17, t=-3.624, p$-value $=0.0025, b=-666.9$, $\left.r^{2}=0.4669\right)$ B) Linear regression for mean site achene width vs. years calibrated $B P(n=17, t=-3.187, p$-value $<0.00612, b=-$ 959.9, $\left.r^{2}=0.4037\right)$ C) Linear regression for achene width vs. years calibrated BP ( $n=994, t=-10.71, p$-value $<0.0001, b=-$ $\left.\left.126.04, r^{2}=0.1037\right) D\right)$ Linear regression for achene width vs. years calibrated $B P(n=994, t=-10.26, p$-value $<0.0001, b=-$ $230.85, r^{2}=0.0964$ ). 


\section{Radiocarbon Dates}

All dates are radiocarbon laboratory results calibrated in OxCal 4.2 Online (Bronk Ramsey 2010), using the median and its two-sigma range. The presentation of this median rather than the range is used for input into statistical programs, and retained throughout the text for coherence. One exception to these calibrated radiocarbon dates is Thor's Hammer, whose single radiocarbon date (from surface material) is inconsistent with archaeological indicators that point to an Early Late Woodland period occupation. For this reason, Thor's Hammer has been assigned the Early Woodland date of $1350 \mathrm{BP}$, so that its raw measurements could be incorporated into the regressions below.

\section{Results}

We used linear regression to assess the statistical significance and rate of change in seed length and width over time for the 17 samples for which radiocarbon samples and site means were available. The closeness of fit of multiple measurements, expressed in the coefficient of determination $\left(\mathrm{r}^{2}\right)$, shows how much of an effect chronological placement in years cal BP has on seed length and width. First, we tested whether length and width consistently had an effect on the other to see whether they indeed seemed to be evolving at the same rate. The fit was highly significant ( $p$-value $<0.001)$, at $\mathrm{r}^{2}=0.89$. The slope with width on the $\mathrm{y}$-axis was $\mathrm{b}=1.46$, and similarly, the covariance between length and width was consistent at all quartiles at 1.22. Length $(n=17, \mathrm{t}=-3.624, p$-value $=0.0025, \mathrm{~b}=-666.9$, $\left.\mathrm{r}^{2}=0.4669\right)$ and width $(n=17, \quad \mathrm{t}=-3.187, \quad p$ value $\left.<0.00612, b=-959.9, r^{2}=0.4037\right)$ of marshelder achenes both increased statistically significantly, albeit gradually, over time (Figures 2A and 2B). Chronological placement explains about $40 \%$ of the variation in size. Notice that although length and width correlate neatly in the other tests, when plotted directly against calibrated years $\mathrm{BP}$, the rates of change expressed in the beta, or slope, differ notably. When interpreted literally, it would take an average of 667 years for marshelder achenes to grow one millimeter longer, while it would take an average of 960 years for achenes to grow one millimeter wider.

Because means can mask variation, we performed a similar analysis using individual achene measurements, which were available from 11 sites (Figure 2C and 2D). For this set of samples-a smaller subset of the previous set of 17-length and width were not as good a fit to a linear regression when set against the other. Although highly significant, ( $p$-value $<0.0001)$, the coefficient of determination was much lower, at $r^{2}=0.3387$. The slope was $b=0.038$ and they covaried at all quartiles at 0.7362 . Using these raw seed lengths and widths, time accounted for only about $10 \%$ of the variation in length $(n=994, \mathrm{t}=-10.71, p$-value $<0.0001, \mathrm{~b}=-126.04$, $\left.\mathrm{r}^{2}=0.1037\right) \quad$ and width $(n=994, \quad \mathrm{t}=-10.26, \quad p$ value $\left.<0.0001, \quad b=-230.85, \quad r^{2}=0.0964\right)$. The slope, interpreted as rate of change over years BP, was much lower than with the site means, at 126 years to grow a millimeter longer, and 231 years to grow a millimeter wider. Average achene size therefore does increase significantly over time throughout the region, although it is only weakly correlated with time of deposition. Perhaps this is why Yarnell (1981) found that (achene length) $\mathrm{x}$ (achene width) was not always an accurate predictor of temporal placement. In our analysis, change in average achene size across time is a proxy for the evolutionary forces resulting from human intervention. In other words, time as measured in calibrated years BP, while not causal in and of itself, we use as a causal variable in our regressions. We assume that residual variation in size is due to regional, microclimatological, and seasonal effects such as average temperature, average rainfall, exposure to sunlight, and time of harvesting. Such variables have the ability to affect plastic traits during seed and fruit development and may explain the relatively poor fit of achene metrics to the slope of the regression. Sources of variation other than calibrated years before present could also include taphonomic factors from depositional contexts to recovery techniques. Another reason for the poor fit may be ongoing gene flow from free-living wild marshelder populations. Sympatric wild populations would likely have frequently contributed their windborne pollen to plants growing in garden plots. We explore these possibilities further in the next section.

To assess patterns of size variation across time and space, we divided sites with marshelder into four regions: Appalachian Plateau, which includes the Cumberland Escarpment and two samples from the Carolinas; Inland Low Plateau, which includes western Kentucky and Tennessee; Central Lowlands, which includes the lower Illinois River valley and the American Bottom; and the Ozark Plateaus which include sites from Missouri and Arkansas. The sample size of mean lengths from each of Yarnell's 23 sites (1981) was increased to 50 by using his same sites, 

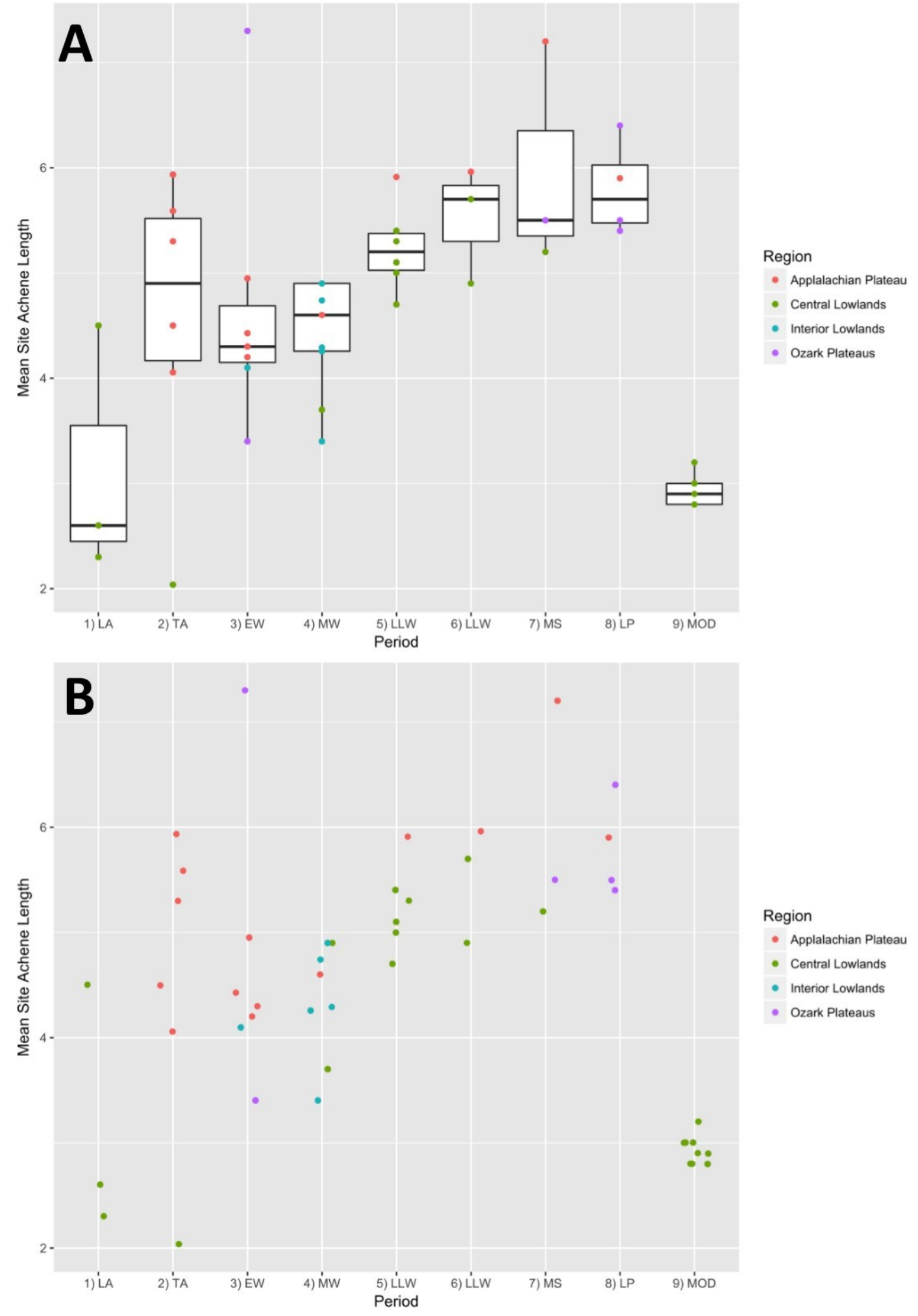

Figure 3 A) Boxplot on strip chart of mean site achene length by archaeological period. Boxplots show mean, interquartile range, and outliers of multiple sites per period $(n=50)$ B) Strip chart of mean site achene length by archaeological period $(n=50)$. 
incorporating new data, then assigning a period, as radiocarbon dates were not readily available for most site contexts. Although some sites had multiple components, measurements were taken only from features with the period designation assigned by the excavators. It becomes immediately evident from plotting achene length (Figures 3A, 3B) that the extreme differences between early wild-sized achenes in Illinois, and later domesticates from throughout the region, has a large influence on the linear regression of achene size against time and the appearance of the trend. Regional trends outside of the Central Lowland sites are not as pronounced as our regression analysis implies, and each has its own trajectory over time. Domestication of marshelder and subsequent diffusion to other regions anthropogenically should result in each region having its own typical achene size distribution. Domesticated marshelder would then form a cline with domesticated populations in adjacent regions. This hypothesis was tested by comparing the distributions of individual achene lengths in various samples. An ANOVA Tukey posthoc analysis revealed homogeneous subsets of sites mostly along regional lines (Supplemental Table 2, Figures 4A and 4B). Appalachian Plateau sites Cloudsplitter, Hooton Hollow, and Newt Kash have similar distributions, then Newt Kash overlaps with Thor's Hammer, Courthouse Rock, and Rogers/ Haystack. Interior Low Plateau sites are also in the same homogeneous subset, with Salts Cave (Middle), Salts Cave (Upper), and Big Bone Cave all overlapping, and encompassing Cold Oak from the Appalachian Plateau. Salts Cave (Middle) overlaps with many of the Appalachian Plateau sites as well. Smiling Dan, IL overlaps with the Appalachian Plateau sites of Hooton Hollow and Cloudsplitter. Together these homogeneous subsets resemble and are interpreted as a cline. Alred Bluff, Arkansas, Collins, Missouri, and Cahokia-ICT, Illinois are all outliers to this apparent cline. In the case of Terminal Archaic features from Cahokia-ICT, the presence of wild-type marshelder explains its outlier status and contrast with the Middle Woodland Smiling Dan site in the same region. Reasons for the separation of values from the two Ozarks sites are not clear. However, the high-value end of the frequency distributions for Interior Low Plateau overlaps with the low-value end for the Appalachian Plateau. This pattern suggests variation across a geographical cline, as would occur in the case of gene flow between adjacent populations of domesticated marshelder. A more macro-scale ANOVA testing the effect of region on achene size reveals a similar pattern, albeit with less nuance and variation. Each region is distinct from the others $(p$-value $<0.0001)$, except when comparing measurements from Interior Low Plateau sites to Appalachian Plateau sites $(p$-value $=0.9564$ ) (see Figures $4 \mathrm{~A}$ and $4 \mathrm{~B}$ for visual representation). We hypothesized that seed size would show a trend towards decreased variation within each region that parallels the intensifying selective pressure of domestication and, in some areas, the absence of gene flow with wild populations. Coefficients of variation (CVs) with 95\% confidence intervals (Steel and Torrie 1980; Verill 2013, Verill and Johnson 2007) were compared to show how phenotypic variability differs by site, region, time period, and domesticate status. A linear regression of $\mathrm{CV}$ against years cal BP proved not to be significant, $\left(\phi\right.$-value $\left.=0.5996, \mathrm{r}^{2}=0.0259\right)$ with the sites used, showing that CV of phenotype does not reflect a reduction of achene size variation in any of the sampled sub-regions. Modern wild populations (Asch and Asch 1978) are not too different in CV than their archaeological counterparts (Figure 5). The CV for Cahokia-ICT is much higher than that recorded for some of the modern wild populations.

Although mean achene size increases over time, the regression analysis shows that intrapopulational phenotypic variation in marshelder achene size does not decrease as predicted and does not differ between domesticated and wild types found archaeologically. Modern wild populations gathered from single stands can serve as a baseline that should capture variation as it exists in a particular time and place, eliminating the possibility that multiple populations are being sampled (Figure 5). One obvious exception is the Terminal Archaic site of Cahokia-ICT. This site, again, is one of the earlier ones represented in the Central Lowlands, and the variation observed seems to be due to the presence of both wild and domesticated size achenes in the sample. Alred Bluff is within the range of variation of modern harvested stands, but the mean of marshelder lengths is second highest. Fluctuations in variation of achene size are either due to introgression between wild and domesticated stands, archaeobotanical preservation, and/or problematic sampling between time periods. It is assumed that introgression in this case would result in the simultaneous existence of both the wild and domesticate form. Archaeobotanical preservation is nearly impossible to control for in this regard. Although there is no evidence that either Cahokia- 

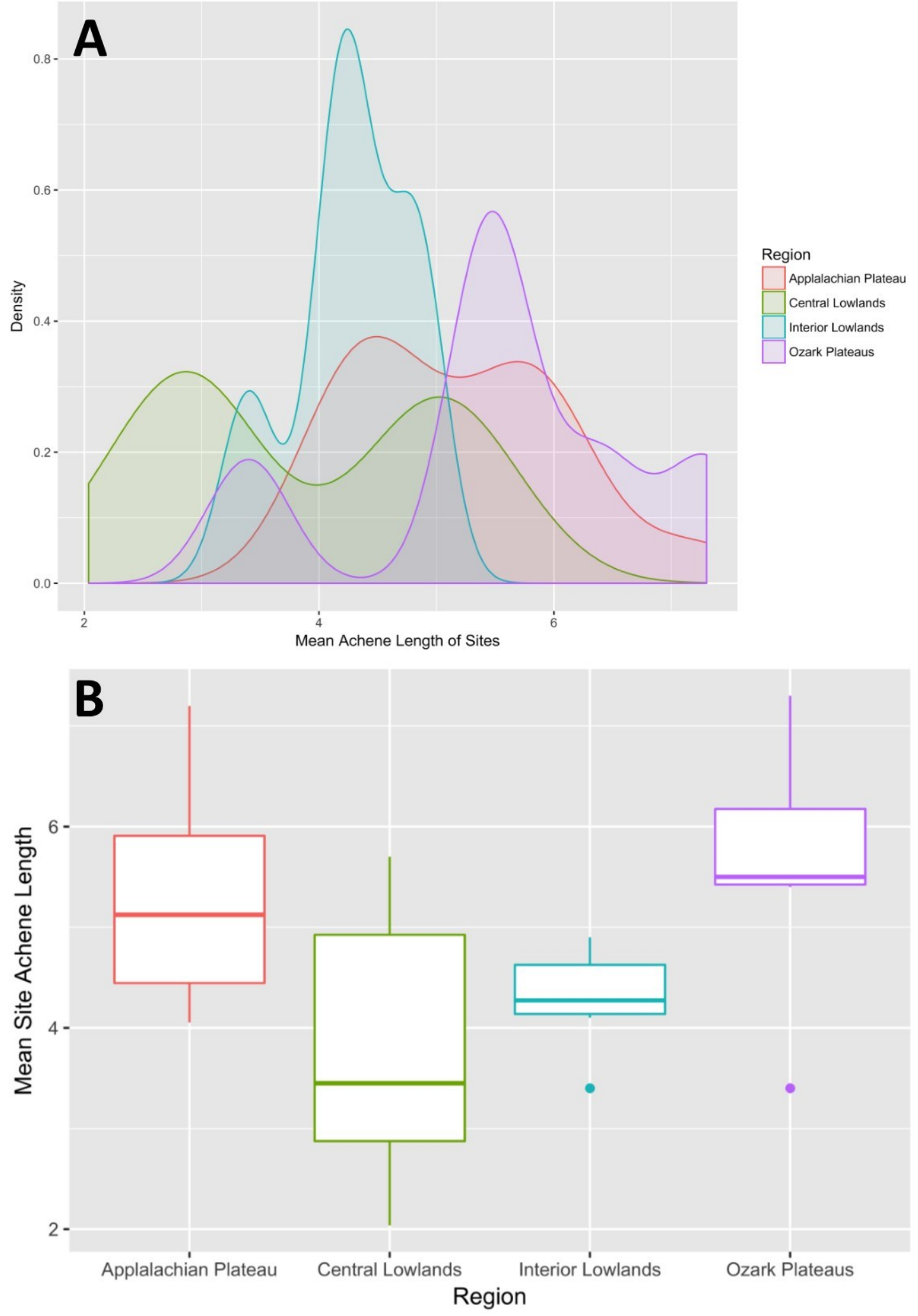

Figure 4 A) Density of various lengths of marshelder by region based on site means $(n=50)$. B) Boxplot of mean site achene length by region $(n=50)$. Boxplots show mean, interquartile range, and outliers of multiple sites per region. 


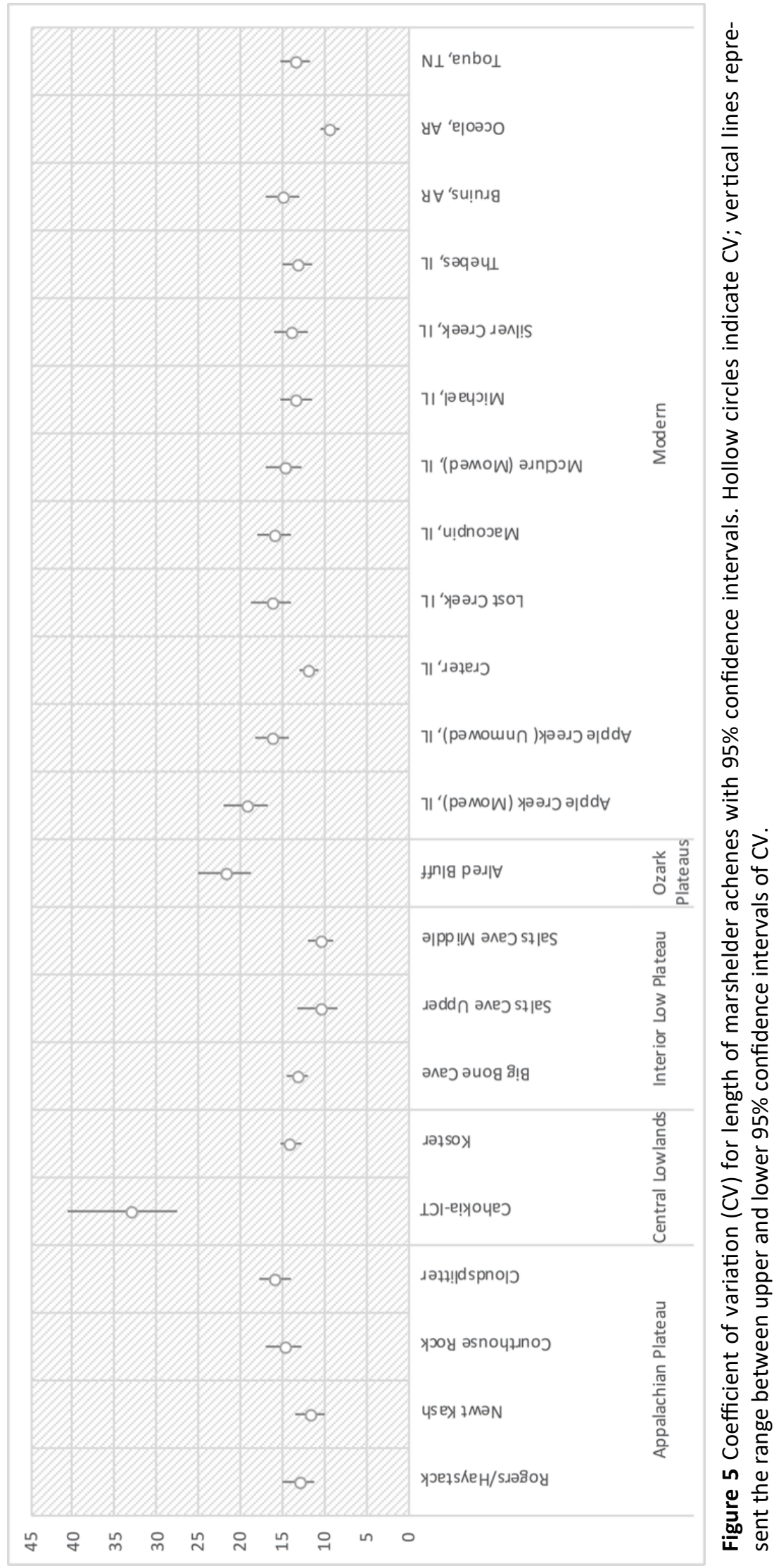


ICT or Alred Bluff had issues, problematic sampling and reporting are difficult to control for when using secondary data sets. Admittedly, determining what a sample represents is at the core of the difficulty in using CV as a measure of domestication patterns. Even in features where disturbance, sampling, and radiocarbon dates are not problematic, difficulty exists. Does the archaeological sample represent a single deposit from one plant at one collection site, or does it represent multiple deposits from one or two hundred years of collection from many stands located in many different microclimates? $\mathrm{CV}$, therefore, may be measuring any one of these scenarios, and not providing information about introgression or isolation. If marshelder measurements are assigned specific provenience and exist in a distinct temporal frame, then it is more likely to measure introgression.

If it is introgression causing the high CV in Alred Bluff and Cahokia-ICT samples, then this provides more evidence for human introduction of marshelder into the Appalachian Plateau and Interior Low Plateau. The relatively low CVs of Appalachian Plateau samples may indicate a lack of introgression, meaning that there were no wild stands with which to cross-pollinate. If there were few to no wild stands in the Appalachian Plateau, which seems likely given wild marshelder's infrequent occurrences that far east today and the lack of wild-sized achenes in archaeological collections, then it is likely marshelder was introduced either through migration or cultural diffusion into that region. If the archaeological record of the Appalachian Plateau instead showed the wild form of marshelder spreading out of its natural range to new areas, we could argue for an unintended introduction, or a gradual evolutionary trajectory following a polyphyletic version of the floodplain weed theory of domestication. However, available evidence points to the process described in the floodplain weed theory (Anderson 1956; Harris 1990; Smith 1992) taking place elsewhere.

\section{Discussion}

While larger achenes are a trend, circumstances leading to larger marshelder achenes are not the same across eastern North America. Some sites exist outside of the neat homogeneous subsets (Supplemental Table 2). Alred Bluff, Arkansas and Collins, Missouri sites are outliers in the Ozark Plateaus, while Cahokia-ICT, Illinois is an outlier from the Central Lowlands. These three sites could have introgressed with wild stands in the natural range

Weiland and Gremillion. 2018. Ethnobiology Letters 9(2):75-89 of wild marshelder, while the overlap between the Appalachian Plateau and Interior Low Plateau represents a similarity between domesticated marshelder populations, perhaps cross-pollinating somewhere in central Kentucky, where the two domesticates came into contact, creating a cline of domesticated marshelder.

Marshelder is not abundant in the modern Appalachian Plateau. Modern distribution has been extrapolated to prehistory (Black 1963), implying a later introduction either by humans or flooding (Smith et al. 1992). Marshelder introduction to the Appalachian Plateau can be explained by one of the three following scenarios: 1) domesticated marshelder from the west was imported through human diffusion or migration, and maintained in its domesticate form; 2) wild-sized marshelder from the west was imported through human diffusion or migration, and plants responded to the new environment with larger achene size; or 3) wild-sized achene bearing plants were dispersed from the west without human intervention, and plants responded to the new environment with larger achene size.

The first scenario seems most likely. The stability of achene size over time in the Appalachian Plateau with no dramatic increase in size supports the hypotheses of a human introduction of an alreadydomesticated marshelder. Similarly, the comparatively "normal" CV provides evidence for a relatively homogenous population. This homogeneity is expected given the assumed lack of wild stands of marshelder in the Appalachian Plateau, which would have prevented gene flow and introgression between populations. Unless there was a rapid and expansive selection against the wild form of marshelder, the expectation for the second two scenarios would be that wild plants responding to the new environment would phenotypically exhibit a mixture of traits characteristic of both wild and domesticated forms. Therefore, we would expect a very high CV, which we do not observe in the Appalachian Plateau.

Allaby's (2010:938) observation that domestication may not be possible without translocation of the plant out of its biogeographical range is most interesting for this discussion. Is it possible that marshelder had to be imported into the geographic isolation of the Appalachian Plateau or elsewhere before it could be domesticated? Could it have its natural range in the Illinois River Valley, and other parts of the Mississippi River drainage, but achieve full domestication only after a bottleneck in a

\section{Weiland and Gremilion. 2018. Ethnobiology Letters $9(2): 75-89$}


geographically isolated region? Domestication of plants necessitates some level geographic isolation, but rarely reproductive isolation to the point of speciation (Harlan et al. 1973). There is no evidence that intensive harvesting of wild stands alone can have a genetic effect on populations of plants selected by humans (Harlan et al. 1973; Yarnell 1972). Therefore, there must be some level of intentionality to the domestication process, either by: 1) moving a plant from its natural range; 2) changing the selective environment through land management; or 3) intentionally isolating domesticates from their wild relatives through garden plot location or harvesting practices.

\section{Conclusion}

Regardless of the origins of domesticated marshelder, the fact remains that it is ubiquitous in archaeological deposits that span multiple cultures and multiple subsistence strategies from the Late Archaic through the Late Prehistoric. Marshelder is found in contexts representing a range of social forms, from the seminomadic peoples of eastern Kentucky to the great Cahokian polity. Evidence suggests that it played a role in both immediate-return and delayed-return economies (Woodburn 1982) and in contexts associated with hunter-gatherers and agriculturalists as classically defined. Most of the societies using domesticated marshelder, however, belong to the "middle ground" of mixed subsistence strategies such as the "low-level food production" that characterizes a great deal of the prehistory of eastern North America, beginning in the Late Archaic (Smith 2001). This reliance upon some crops that have been incorporated into a general hunting-gathering subsistence strategy is problematic for any attempt to replicate a unilineal model of food production. The archaeological record in general and seed morphology specifically contradict this stage of mixed economy as merely transitional. Rather, evolution of marshelder achene size implies relatively large-scale manipulations of the landscape by people utilizing this crop.

\section{Acknowledgements}

Thanks to George Crothers and Charles T. Faulkner for their generosity in passing on raw data.

\section{Declarations}

Permissions: Not applicable.

Sources of Funding: None declared.

Conflicts of Interest: None declared.

\section{References Cited}

Allaby, R. 2010. Integrating the Processes in the Evolutionary System of Domestication. Journal of Experimental Botany 61:935-944. DOI:10.1093/jxb/ erp382.

Anderson, E. 1956. Man as a Maker of New Plants and New Plant Communities. In Man's Role in Changing the Face of the Earth, edited by W. L. Thomas, pp. 763-777. University of Chicago Press, Chicago, IL.

Asch, D.L. and N.B. Asch. 1978. The Economic Potential of Iva annua and its Prehistoric Importance in the Lower Illinois Valley. In The Nature and Status of Ethnobotany, edited by R. I. Ford, pp. 300-346. Museum of Anthropology Anthropological Papers, University of Michigan, Ann Arbor, MI.

Asch, D.L. and N.B. Asch. 1985. Prehistoric Plant Cultivation in West-Central Illinois. In Prehistoric Food Production in North America, edited by R. I. Ford, pp. 149-204. Museum of Anthropology Anthropological Papers, University of Michigan, Ann Arbor, MI.

Black, M. 1963. The Distribution and Archaeological Significance of the Marshelder Iva annua L. Papers of the Michigan Academy of Science, Arts and Letters XLVIII:541-547.

Blake, S.F. 1939. A New Variety of Iva ciliata from Indian Rock Shelters in the South-Central United States. Rhodora 41:81-86.

Chapman, J. and A.B. Shea. 1981. The Archaeobotanical Record: Early Archaic Period to Contact in the Lower Little Tennessee River Valley. Tennessee Anthropologist 6:62-84.

Cowan, C.W. 1979. Excavations at the Haystack Rockshelters, Powell County, Kentucky. Midcontinental Journal of Archaeology 4:3-33. DOI:10.2307/20707828.

Cowan, C.W. 1985. Understanding the Evolution of Plant Husbandry in Eastern North America: Lessons from Botany, Ethnography, and Archaeology. In Prehistoric Food Production in North America, edited by R. I. Ford, pp. 205-243. Museum of Anthropology Anthropological Papers, University of Michigan, University of Michigan, Ann Arbor, MI.

Crites, G.D. 1993. Domesticated Sunflower in Fifth Millenium BP Temporal Context: New Evidence from Middle Tennessee. American Antiquity 58:146148. DOI:10.2307/281459. 
Faulkner, C.T., and G.M. Crothers. 1991. Morphological Variation in Iva annua Achenes: A Statistical Analysis of Archaeological Collections from Eastern North America. Paper presented at the 14th Annual Meeting of the Society of Ethnobiology, St. Louis, MO.

Fritz, G.J. 1986. Prehistoric Ozark Agriculture: The University of Arkansas Rockshelter Collections. Doctoral Dissertation, Department of Anthropology, University of North Carolina at Chapel Hill, Chapel Hill, NC.

Fuller, D.Q. 2007. Contrasting Patterns in Crop Domestication and Domestication Rates: Recent Archaeological Insights from the Old World. Annals of Botany 100:903-924. DOI:10.1093/aob/mcm048.

Fuller, D.Q., E. Asouti and M.D. Purugganan. 2012. Cultivation as Slow Evolutionary Entanglement: Comparative Data on Rate and Sequence of Domestication. Vegetation History and Archaeobotany 21:131-145. DOI:10.1007/s00334-011-0329-8.

Gilmore, M. 1931. Vegetal Remains of the Ozark Bluff-Dweller Culture. In Michigan Academy of Science Arts and Letters14. University of Michigan, Ann Arbor, MI.

Gremillion, K.J. 1993. The Evolution of Seed Morphology in Domesticated Chenopodium: An Archaeological Case Study. Journal of Ethnobiology 13:149-169.

Gremillion, K.J. 1996. Early Agricultural Diet in Eastern North America: Evidence from Two Kentucky Rockshelters. American Antiquity 61:520536. DOI:10.2307/281837.

Gremillion, K.J. 1997. New Perspectives on the Paleoethnobotany of the Newt Kash Shelter. In People, Plants, and Landscapes, edited by K. J. Gremillion, pp. 23-41. University of Alabama Press, Tuscaloosa, AL.

Gremillion, K.J. 2004. Seed Processing and the Origins of Food Production in Eastern North America. American Antiquity 69:215-233. DOI:10.2307/4128417.

Harlan, J.R., J.M.J. de Wet, and E.G. Price. 1973. Comparative Evolution of Cereals. Evolution 27:311-325. DOI:10.2307/2406971.

Harris, D.R. 1990. Vavilov's Concept of Centres of Origin of Cultivated Plants: Its Genesis and Its Influence on the Study of Agricultural Origins.
Biological Journal of the Linnean Society 39:716. DOI:10.1111/j.1095-8312.1990.tb01608.x.A.

Jackson, R.C. 1960. A Revision of the Genus Iva L. The University of Kansas Science Bulletin XLI:793-875.

Jones, V.H. 1936. The Vegetal Remains of Newt Kash Hollow Shelter. In Rockshelters in Menifee County, Kentucky, edited by W.S. Webb and W.D.

Funkhauser, pp. 147-165. University of Kentucky Reports in Anthropology and Archaeology, Lexington, $\mathrm{KY}$.

Leishmann, M R., I.J. Wright, A.T. Moles, and M. Westboy. 2001. The Evolutionary Ecology of Seed Size. In Seeds: The Ecology of Regeneration in Plant Communities, $2^{\text {nd }}$ edition, edited by M. Fenner, pp. 31-50. Oxford University Press, Cabi Pub, Wallingford, UK.

Linton, R. 1924. The Significance of Certain Traits in North American Maize Culture. American Anthropologist 26:345-349. DOI: 10.1525/ aa.1924.26.3.02a00050.

Mueller, N.G. 2017 Documenting Domestication in a Lost Crop (Polygonum erectum L.): Evolutionary Bethedgers Under Cultivation. Vegetation History and Archaeobotany 1:1-15. DOI:10.1007/S00334-0160592-9.

Mueller, N.G., G.J. Fritz, P. Patton, S. Carmody, and E.T. Horton. 2017. Growing the Lost Crops of Eastern North America's Original Agricultural System. Nature Plants 3:7. DOI:10.1038/ nplants.2017.92.

Nassaney, M.S., N.H. Lopinot, B.M. Butler, and R.W. Jefferies. 1983. The 1982 Excavations at the Cahokia Interpretive Center Tract, St. Clair County, Illinois. Illinois Department of Conservation Division of Historic Sites.

National Geographic, i-cubed. 2013. Topographic Map [basemap]. Scale Not Given. USGS Topographic Maps. Available at:https:// www.arcgis.com/home/item.html?

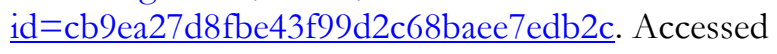
May 16, 2018.

Ramsey, C.B., M. Dee, S. Lee, T. Nakagaw, and R. Staff. 2010. Developments in the Calibration and Modelling of Radiocarbon Dates. Radiocarbon 52:953-961. DOI:10.1017/S0033822200046063.

Smith, B.D. 1985. The Role of Chenopodium as a Domesticate in Pre-Maize Garden Systems of the Eastern United States. Southeastern Archaeology 4:5172. 
Smith, B.D. 2001. Low-Level Food Production. Journal of Archaeological Research 9:1-43. DOI:10.1023/ A:1009436110049.

Smith, B.D. 2006 Documenting Domesticated Plants in the Archaeological Record. In Documenting Domestication: New Genetic and Archaeological Paradigms, edited by M.A. Zeder, D.G. Bradley, E. Emshwiller, and B.D. Smith, pp. 15-24. University of California Press, Berkeley, CA.

Smith, B.D. 2011. The Cultural Context of Plant Domestication in Eastern North America. Current Anthropology Supplement:S471-S484. DOI:10.1086/659645.

Smith, B.D., C.W. Cowan and M.P. Hoffman. 1992. Rivers of Change: Essays on Early Agriculture in Eastern North America. Smithsonian Institution Press, Washington, DC.

Smith, B.D. and R.A. Yarnell. 2009. Initial Formation of an Indigenous Crop Complex in Eastern North America at 3800 BP. Proceedings of the National Academy of Sciences 106:6561-6566. DOI:10.1073/ pnas.0901846106.

Stafford, B.D., M.B. Sant, and D.L. Asch. 1985. Smiling Dan: Structure and Function at a Middle Woodland Settlement in the Lower Illinois V alley. Published for the Illinois Dept. of Transportation by the Center for American Archeology, Kampsville Archeological Center, Kampsville, IL.

Steel, R.G.D. and J.H. Torrie. 1980. Principles and Procedures of Statistics: A Biometrical Approach. McGraw-Hill, New York, NY.
USDA, NRCS. 2017. The PLANTS Database. National Plant Data Team, Greensboro, NC 274014901 USA. Available at: http://plants.usda.gov. Accessed December 12, 2017.

Verill, S. 2013. Exact Confidence Bounds for a Normal Distribution Coefficient of Variation. Forestry Service, Department of Agriculture. Available at http://www1.fpl.fs.fed.us/ covnorm.dcd.html. Accessed December 12, 2017.

Verrill, S. and R.A. Johnson. 2007. Confidence Bounds and Hypothesis Tests for Normal Distribution Coefficients of Variation. Communications in Statistics: Theory and Methods 36:2187-2206. DOI:10.1080/03610920701215126.

Weiland, A.W. 2013. Marshelder (Iva annua L.) Seed Morphology and Patterns of Domestication in Eastern North America. Master's Thesis, Department of Anthropology, The Ohio State University, Columbus, $\mathrm{OH}$.

Woodburn, J. 1982. Egalitarian Societies. Man 17:431451. DOI:10.2307/2801707.

Yarnell, R.A. 1972. Iva annua var. macrocarpa: Extinct American Cultigen? American Anthropologist 74:335341.

Yarnell, R.A. 1981. Inferred Dating of Ozark Bluff Dweller Occupations Based on Achene Size of Sunflower and Sumpweed. Journal of Ethnobiology 1:55-60. 